\title{
Disfavored for the Color of Their Skin: Black Women Workers in the World War II Shipyards of Portland and Vancouver
}

Tessara G. Dudley

Portland State University

Follow this and additional works at: https://pdxscholar.library.pdx.edu/mcnair Let us know how access to this document benefits you.

\section{Recommended Citation}

Dudley, Tessara G. (2019) "Disfavored for the Color of Their Skin: Black Women Workers in the World War II Shipyards of Portland and Vancouver," PSU McNair Scholars Online Journal: Vol. 13: Iss. 1, Article 9. https://doi.org/10.15760/mcnair.2019.13.1.9 
Disfavored for the Color of Their Skin: Black Women Workers in the World War II Shipyards of Portland and Vancouver

Tessara Dudley

Shirley Jackson, Faculty Mentor

Introduction

The Second World War saved many Americans from the deprivation and desperation of the Great Depression. Workers and their families left the US South for the North and the Northeast for the West, in the second wave of the Great Migration. Defense industries such as shipbuilding and aircraft construction transformed small towns and modest urban centers into 'boomtowns,' where local governments scrambled to supply sufficient housing for migrant workers hoping to secure lucrative war work. Among these migrants were thousands of Black Americans, who were determined to leave behind the discrimination and degradation of the Jim Crow South. For Black women, this included leaving behind poorly-paid domestic labor in the homes of white Americans, in favor of the public service sector and - if they could get itdefense industry work. As small Black populations in the North and West mushroomed into large ones, many Black women found their hopes for better jobs thwarted by white populations determined to restrict access to war work. This was particularly true in the Pacific Northwest, where a tiny pre-war Black population bloomed into a large population, exciting the anxieties and ire of the white population in a state that was founded to be a white homeland. Though Black women struggled and persisted, and even despite the persistent need for all available workers, they were effectively blocked from accessing the high wages of defense work, and locked into the most devalued work available. 
Much of the historiography about Black participation in the World War II labor effort has focused on boomtowns, the cities and towns that experienced a massive influx of migrant laborers seeking work to support the war effort. In particular, cities which either had a large prewar Black population or sustained a large Black population after the war have seen more scholarly examination. While scholars have studied the World War II-era experiences of Black communities and Black women workers in areas of the country with large Black populations before the US entered the war, and those with large Black populations in the decades immediately following the end of the war, the World War II experiences of Black women in Portland and Vancouver are largely absent from these accounts. This paper seeks to address this hole in the scholarship by highlighting the experience of Black women workers in the predominantly white Pacific Northwest.

During the war, many defense industry employers complained of labor shortages which prevented them from meeting the terms of their contracts, and the existence of such shortages spurred a great deal of government action to promote defense industry work, including the campaign to recruit women workers which featured the now-classic "Rosie the Riveter" icon. In the 1980s and 1990s, scholars began to question the narrative that a severe shortage of labor was slowing production. ${ }^{1}$ These scholars have examined the experiences of Black women and shown the discrimination faced at the intersection of race and gender: whereas white women and Black men made some gains in the trades, Black women faced additional resistance because of their dual identities as women and Black people. As a result, Black women were severely restricted in terms of the work they could access. In many cities, Black women workers faced "hate strikes"

\footnotetext{
${ }^{1}$ See: Karen Anderson, "Last Hired, First Fired: Black Women Workers During World War II," Journal of American History 69, no. 1 (1982): 82-97; also, Amy Kesselman, Fleeting Opportunities: Women Shipyard Workers in Portland and Vancouver During World War II and Reconversion (Albany: State University of New York Press, 1990).
} 
by white women who objected to sharing facilities with them. It is likely that many employers held the same prejudices as their workers and used the possibility of hate strikes to justify not hiring Black women. ${ }^{2}$ On the other hand, some employers pressured white women into returning to work by evoking their sense of national duty. Employers who hired Black women created segregated facilities, limiting Black women to the hardest and dirtiest jobs, and restricting them to separate lunchrooms and toilets. ${ }^{3}$ Segregation was taken to extremes, as in the case of an Indiana munitions plant, which went so far as to provide segregated bomb shelters. ${ }^{4}$

Nationally, the experience of Black women workers attempting to break into defense industries was impacted by a number of different factors, including region, industry, union affiliation, and skill designation. Black auto industry workers in Detroit found a strong ally for integration in the United Auto Workers, a union affiliated with the Congress of Industrial Organizations (CIO), which joined the federal Fair Employment Practices Committee (FEPC) to end hate strikes and support the internal promotion of Black women workers to higher positions. ${ }^{5}$ Two major Black civil rights organizations, the National Association for the Advancement of Colored People (NAACP) and the Urban League, also assisted Black workers in filing complaints with the FEPC. ${ }^{6}$ In Indiana and Chicago, Black women wrote to President and First Lady Roosevelt, as well as the FEPC, with their complaints, ${ }^{7}$ demanding access not just to war jobs, but affordable housing ${ }^{8}$ integrated public accommodations, and other things they

\footnotetext{
${ }^{2}$ Anderson, "Last Hired, First Fired," 86-87.

${ }^{3}$ Anderson, "Last Hired, First Fired," 86-88.

${ }^{4}$ Katherine Turk, “'A Fair Chance to Do My Part of Work': Black Women, War Work, and Rights Claims at the Kingsbury Ordnance Plant," Indiana Magazine of History 108, no. 3 (2012): 226-27.

${ }^{5}$ Megan Shockley, "Working for Democracy: Working Class African-American Women, Citizenship, and Civil Rights in Detroit, 1940-1954," Michigan Historical Review 29, no. 2 (2003): 137-38.

${ }^{6}$ Shockley, "Working for Democracy," 137-38.

7 Turk, "A Fair Chance," 229-30.

${ }^{8}$ Lionel Kimble, Jr., "I Too Serve America: African American Women War Workers in Chicago, 19401945," Journal of the Illinois State Historical Society 93, no. 4 (2000/2001): 425-29.
} 
considered marks of citizenship. ${ }^{9}$ The success of these demands varied across the country, but in places such as Detroit, Chicago, Richmond (California), and Indiana, Black women determined to leave private service in white homes pushed their way into war industries as riveters, welders, and assembly line workers, using government and community organizations to gain access to lucrative war work. As this paper will show, Black women seeking the same war work in Oregon and Southern Washington used many of the same tactics, but did not meet with similar successthey were continuously and almost universally blocked from lucrative war jobs.

This paper focuses on Portland, Ore., and Vancouver, Wash., for several reasons. The Portland area has historically been the location of most of the Black population in Oregon, and was the location of five shipyards during the war, ${ }^{10}$ making it the primary focus for discussing Black shipyard workers in Oregon. Vancouver is included because of it's close proximity to Portland, the location of a Kaiser Corporation-owned shipyard in Vancouver, and the significant control exerted over Vancouver's yard by the Portland-based Local 72 of the International Brotherhood of Boilermakers, Iron Ship Builders, and Helpers of America. Due to the very small size of Vancouver's Black population, however, there is little information regarding its existence prior to 1940. This paper draws on physical and digital materials from archives in Portland, Ore., Seattle, and Vancouver, Wash., including transcripts for interviews conducted by other researchers, private manuscripts, and documentation from local businesses and non-profit organizations. Additionally, data from the US Census Bureau was used to determine population and employment numbers and occupations. Several historical newspapers were also consulted, particularly the Oregonian and the New York Times.

\footnotetext{
9 Turk, “A Fair Chance,” 219-20.

${ }^{10}$ Willamette Iron and Steel, Commercial Iron Works, Albina Engine Works, and two Kaiser-owned yards: Oregon Shipbuilding Corporation and Swan Island Shipyard
} 
Blacks in Oregon and Southern Washington

Oregon has a long history of discriminatory treatment against Black people and other people of color. Three racial exclusion laws were considered or passed in the 1800 s by the legislative body of the Oregon Territory, the most infamous of which — the 1844 'Lash Law' stipulated that any Black person found living in the territory could be arrested and publicly whipped as often as every six months that they continued to reside within its borders. ${ }^{11}$ Oregon holds the dubious distinction of being the only state admitted to the union with a constitution which included both a clause banning slavery and a clause banning residence by free Black people. ${ }^{12}$ Within a decade, the Democratic Party-largely pro-Confederate and anti-Black—held majorities in both the Oregon House and Senate, which moved quickly to "rescind Oregon's ratification of the fourteenth amendment," and redistrict the state to strengthen their position in every district. ${ }^{13}$ While there is record of only one open lynching in Oregon's history, ${ }^{14}$ Black residents of the state believed there to be more, and frequently called upon city and state government to move openly against the Ku Klux Klan, though they were often met with a lackluster response from officials. ${ }^{15}$ In fact, Democrat governor Walter Pierce, elected in 1922, was openly associated with the Klan; he was elected because the Klan used its influence to unseat his predecessor, who was an outspoken opponent of their activities. ${ }^{16}$

\footnotetext{
${ }^{11}$ Elizabeth McLagan, A Peculiar Paradise: A History of Blacks in Oregon, 1788-1940 (Portland: Georgian Press Company, 1980), 25-28.

${ }^{12}$ Mclagan, A Peculiar Paradise, 28.

${ }^{13}$ Robert Johannsen, "The Oregon Legislature of 1868 and the Fourteenth Amendment," Oregon Historical Quarterly 51, no. 1 (1950): 4.

${ }_{14}$ McLagan, A Peculiar Paradise, 135-37.

${ }^{15}$ Kimberly Mangun, A Force for Change: Beatrice Morrow Cannady and the Struggle for Civil Rights in Oregon, 1912-1936 (Corvallis: Oregon State University Press, 2010), 142-45.

${ }^{16}$ Mangun, A Force for Change, 270n24.
} 
It is important to note, however, that each instance of legalized discrimination was vigorously protested by residents both Black and white, ${ }^{17}$ and that the Portland chapter of the NAACP is the oldest continuously-running chapter west of the Mississippi River. ${ }^{18}$ Additionally, the state of Washington was less overtly discriminatory, lacking the racial ban of Oregon's constitution. Washington had a Black population 2.9 times the size of Oregon's in $1940,{ }^{19}$ and 2.7 times the size of Oregon's in $1950,{ }^{20}$ which suggests local Black populations may have found jobs and accommodations more easily over the border. Whether in Oregon or Washington, Black community members and white allies confronted with discriminatory laws and practices responded with letter campaigns, petitions, newspaper editorials, public meetings, pickets, and other tactics. ${ }^{21}$ Despite discrimination, Black people in the Pacific Northwest have consistently shown themselves ready to fight for their rights.

The 1940 United States census shows 2,565 Black people living in the state of Oregon; of these, 1,931 lived in the Portland metropolitan area. ${ }^{22}$ The census recorded 10 Black people living in Vancouver, Washington, ${ }^{23}$ and published no information on the Black labor force. Before the US entered World War II, Black workers in Portland were heavily concentrated in public and private service work. In the state of Oregon, 279 working Black women were listed, $54.12 \%$ of them in private domestic service, and an additional $34.05 \%$ of them in other service

${ }^{17}$ Mangun's A Force for Change and McLagan's A Peculiar Paradise show numerous examples of this prior to 1940. See also much of the work produced by Dr. Quintard Taylor.

18 "History - Portland NAACP Branch 1120," Portland NAACP, accessed 14 June 2017, http://www.portlandnaacp1120.org/history.html.

${ }^{19}$ Bureau of the Census, 1940 Census of the Population: Characteristics of the Nonwhite Population by Race (Washington, DC: Government Printing Office, 1943), 59.

${ }^{20}$ Bureau of the Census, 1950 Census of the Population, Vol. 4: Employment and Personal Characteristics, Pt. 3, Ch. 4 (Washington, DC: Government Printing Office, 1943), 3B 58-59.

${ }^{21}$ See note 15 .

22 Bureau of the Census, Characteristics of the Nonwhite Population, 59.

${ }^{23}$ Bureau of the Census, 1940 Census of the Population, Vol. 2: Characteristics of the Population, Pt. 7 , Ch. 4 (Washington, DC: Government Printing Office, 1943), 393. 
fields. ${ }^{24}$ (In Washington state, the number was 637, and the percentages were $55.57 \%$ and $28.57 \%$, respectively. $)^{25}$ Black Portlanders knew the jobs open to them were severely limited: outside of private domestic work, women were employed as hat check and janitorial staff for hotels, while men largely worked as wait staff and cooks in hotels, or as cooks, porters, and stewards on the trains. ${ }^{26}$ In the cases where Black men and women were able to find work outside of service work, this often occurred because a white friend was willing to vouch for them; one woman, Kathryn Bogle, recounted the story of her husband's job search in the 1930s. After receiving a job offer from the postal service, he was invited to meet with the postmaster, but when he arrived the post office staff realized he was a light-skinned Black man and he was told that a mistake had been made: there was no job. Almost a month later, Bogle's husband encountered his college roommate — a white man —on the street, and shared the story; his former roommate, incensed, promised to speak with the postmaster, and within three days a new job offer was made..$^{27}$

Bogle also spoke of looking for work before she married: after graduation, her mother encouraged her to seek work, but according to Bogle "she knew, I knew, my father knew, everybody knew that there was no work for me out there, except housework. And everybody, my father, my mother, and I didn't want me to do housework." ${ }^{28}$ At that time, Black workers were barred even from some kinds of work they were commonly relegated to in other parts of the country: there were no Black elevator operators in Portland, ${ }^{29}$ nor were there Black janitors in

\footnotetext{
${ }^{24}$ Bureau of the Census, Characteristics of the Nonwhite Population, 68.

${ }^{25}$ Bureau of the Census, 1940 Census of the Population, Vol. 2, Pt. 7, Ch. 4, 304.

${ }^{26}$ Oral history interviews with Kathryn Hall Bogle, by Rick Harmon, 26 Jun. 1985-28 Mar. 1986, SR 0422, transcript, Oregon Historical Society Research Library, Portland, 33-35.

${ }^{27}$ Oral history interview with Kathryn and Richard Bogle, Sr., by Pat Passmore, 20 Oct. 1976, SR 0280, sound recording, Oregon Historical Society Research Library, Portland.

${ }^{28}$ Interview with Kathryn Hall Bogle, 43.

${ }^{29}$ Interview with Kathryn Hall Bogle, 78.
} 
hospitals, much less Black nurses or orderlies. ${ }^{30}$ Bogle applied to work in various businesses throughout downtown, and was turned away: "I was told there was nothing about me in my disfavor- except the color of my skin!" Several of the employers she saw told her they would not hire her for the work she sought, but that they had openings in their own homes for a private domestic, reaffirming what they saw as the natural place of working Black women. ${ }^{31}$ It was common for Black women—-barred from living in the Oregon State College dormitories- to become live-in domestic workers for white families living near the school, and work their way through college. ${ }^{32}$ Students who wanted to go on to medical school, nursing school, or law school, generally left the state to seek training elsewhere, knowing their opportunities to learn and work in Oregon were highly restricted; many found work elsewhere and never returned. ${ }^{33}$

\section{Black Women Workers in World War II}

In a study of Black women migrant workers in the East Bay Area of California, one scholar noted that the existing Black and white communities of Richmond considered migrant Blacks as "culturally inferior and unassimilable," but that this characterization was eventually erased by the successful integration of Black migrants into the existing community. ${ }^{34}$ In Portland, considering Black migrants unassimilable may have been a more accurate assessment: Southern Black migrant workers hoping for a more liberal cultural environment were confronted by signs in restaurant windows which read "We Cater to White Trade Only" as soon as they

\footnotetext{
${ }^{30}$ Interview with Kathryn Hall Bogle, 63.

${ }^{31}$ Kathryn Bogle, “An American Negro Speaks of Color,” Sunday Oregonian, 14 February 1937, Newsbank/Readex (SQN: 12A4B9C1A0B88FF2).

${ }^{32}$ Interview with Kathryn Hall Bogle, 33.

${ }^{33}$ Interview with Kathryn Hall Bogle, 63.

${ }^{34}$ Gretchen Lemke-Santangelo, Abiding Courage: African American Migrant Women and the East Bay Community (Chapel Hill: University of North Carolina Press, 1996), 77.
} 
stepped off the trains from the east. ${ }^{35}$ Segregated lunch counters, restaurants, hotels, and movie theaters were the rule throughout downtown Portland, ${ }^{36}$ leading many migrant workers to spend their recreational time in the city of Vanport, where such public accommodations were integrated. $^{37}$

Black migrant workers from New York were vocally disgusted with the discrimination they found, and threatened to return to New York if they continued to be blocked from the higher-paying work which they were promised. ${ }^{38}$ Some Southern Black migrant workers, primarily men, were surprised to find themselves excluded even from low-status work they had been allowed to do in the South, such as truck-driving and elevator attendance, while Black women migrants found themselves barred from joining the union for laundry workers. ${ }^{39}$ Many migrants blamed the previous Black community for the degrading conditions under which they were forced to work and live. Some who sought work through the United States Employment Service (USES) vented their frustrations about the discrimination they faced, accusing Black case workers of not doing enough to combat racism. Members of the pre-existing Black community felt frustrated that newcomers refused to understand the previous dynamics of the community or the racial history of the region. ${ }^{40}$ Some migrants from the South, however, accepted the situation with equanimity. Audrey Dotsey, a Black woman migrant worker, told one

35 "Sign in Window of Unidentified Portland Business (Restaurant?) Reads, 'We Cater to White Trade Only," 1943, Jon Tuttle Collection, CN 023381, Oregon Historical Society Research Library, Portland.

${ }^{36}$ Oral history interview with Beatrice Green Marshall, by Madeline Moore and Christine Poole, 11 June 1981, SR 9081, transcript, Oregon Historical Society Research Library, Portland, 30.

${ }^{37}$ Irma Martin, "Vanport," n.d., Irma Martin Manuscripts, Oregon Historical Society Research Library, Portland.

38 "Negro Shipyard Workers Threaten to Quit Work," Oregonian, 17 October 1942, Newsbank/Readex (SQN: 12A9AF779E6B0573).

${ }^{39}$ Interview with Kathryn Hall Bogle, 117.

${ }^{40}$ Interview with Kathryn Hall Bogle, 117-18. 
researcher that she hadn't encountered any discrimination in Portland because she worked at "just staying to myself ... I had lived in the South and I know how they were."

The divisions in the Black community did not, however, prevent community organizing: in the late 1930s and throughout the war, the local NAACP grew increasingly militant, and joined with other local and national organizations to combat discrimination. The NAACP worked with the national Urban League and an advocacy organization formed by Black shipyard workers to protest their treatment. ${ }^{42}$ Despite their efforts, restrictions on Black workers persisted throughout the Second World War, particularly the restricted access to work faced by Black women. In contrast to larger war boom cities, such as Chicago and Oakland, Black women workers in Portland were largely unable to secure high paid, skilled defense industry work. According to a 1944 survey by the Women's Bureau, an agency within the US Department of Labor, discriminatory hiring practices were a common problem in shipyards across the country. Of the 32 yards surveyed by the Women's Bureau, less than half (14) employed Black women, and 7 of these were US Navy yards. ${ }^{43}$ Once hired, Black women workers faced additional discrimination in job classification. Despite undergoing months of training and demonstrating their willingness to work, Black women were restricted to traditionally devalued jobs as cleaners—sweeping the decks and cleaning the outhouses—or employed as 'painter's helpers,' a job which required women to crawl under the ships to scrape off rust in advance of painters. Being painter's helpers left the women extremely dirty at day's end, and eventually damaged the health of women who remained in the job for more than a couple of months, leading them to

\footnotetext{
${ }^{41}$ Oral history interview with Audrey Dotsey, by Amy Kesselman, 15 Jun. 1981, SR 9076, transcript, Oregon Historical Society Research Library, Portland.

42 "Negro Shipyard Workers," Oregonian, 17 October 1942.

${ }^{43}$ Dorothy K. Newman, Employing Women in Shipyards, Bulletin of the Women's Bureau, no. 192-6 (Washington, DC: Government Printing Office, 1944), 16.
} 
either quit or request a transfer to the sweeping crews. Many ultimately left the Portland area for aircraft work in Seattle and LA. ${ }^{44}$ In July 1943, several Black women working as janitors at a Portland shipyard reported their lead man for routinely referring to them using slurs; a Black man who defended them to supervisors was fired. ${ }^{45}$ Black women in Vancouver ostensibly fared better, but still faced harassment on the job. In 1944, six Black women welders from the Vancouver yard complained to the War Manpower Commission about discriminatory discharges: they reported their lead man for mistreating them and using racial slurs, and soon after the women found themselves abruptly moved from graveyard to swing shift_-incompatible with their childcare arrangements - and then discharged and offered day shift positions. They were forced to either quit the yards or take a pay cut and work as common laborers on the graveyard shift. $^{46}$

Even though both Black and white women trained for jobs as welders, aircraft riveters, and drill press operators, there is no evidence that even a single Black woman in the Portland shipyards was employed as a welder or drill press operator. Even Black men in the Portland shipyards were employed only as janitors, chippers, and "tank testers," 47 work which was dirty and frequently arduous. ${ }^{48}$ The Kaiser-owned Vancouver yard boasted a higher number of Black workers than any of the three Portland yards, and a greater percentage of Black workers in skilled and semi-skilled jobs; there is, however, disagreement over precisely how large this

\footnotetext{
${ }^{44}$ Interview with Beatrice Green Marshall, 2-4.

${ }^{45}$ Rudy Pearson, "African Americans in Portland, Oregon, 1940-1950: Work and Living Conditions - A Social History" (doctoral dissertation, Washington State University, 1996), 38.

${ }^{46}$ Kesselman, Fleeting Opportunities, 42-43.

${ }^{47}$ Chippers followed welders and used a hammer to chip off the waste material (also called slag or "dogs") which collected and cooled around a weld. Chipping slag was often both difficult and tedious. Tank testers went below decks to test the double bottom of the ship for leaks, marking where welders needed to come in and reinforce the welds. This work was primarily seen as difficult because it was done in tight spaces and uncomfortable positions.

${ }^{48}$ Martin, "Vanport."
} 
percentage was: Kaiser management claimed that $70 \%$ of Black workers were in skilled work, while an independent researcher in 1943 asserted that 89\% of Black workers held positions designated as unskilled. Official statistics for the Vancouver yards showed women constituted $31 \%$ of the total Black work force, and one-fifth of Black welders and electricians. ${ }^{49}$

\section{Black Workers and Unions}

One main reason for the employment disparity can be found in the unions engaged in shipyard work on the Pacific coast. Whereas Black women workers in Detroit received support from the CIO-affiliated United Auto Workers, unions affiliated with the American Federation of Labor (AFL) were considerably less willing to support Black workers. ${ }^{50}$ The AFL-affiliated International Brotherhood of Boilermakers, Iron Shipbuilders, and Helpers of America (known as the Boilermakers) was the dominant union in Pacific coast and Gulf coast shipyards, and was staunchly opposed to Black membership. In January 1941, the Boilermakers secured "closedshop" agreements with shipyard owners along the Pacific coast, including the Kaiser yards in Portland and Vancouver. ${ }^{51}$ These agreements granted the Boilermakers exclusive rights to the applicable jobs in those yards, and sole discretion over hiring, firing, and promotion. ${ }^{52}$ In other words, if one wanted to do much of the work in the yards, one had to be a member of the local Boilermakers. Determined to reserve their field for white men, union locals shunted Black men and women into segregated auxiliaries. In these 'Jim Crow' auxiliaries, Black workers were

${ }^{49}$ Kesselman, Fleeting Opportunities, 41.

${ }^{50}$ Shockley, "Working for Democracy," 240.

${ }^{51}$ Andrew Kersten, Labor's Home Front: The American Federation of Labor During World War II (New York: NYU Press, 2009), 47-48.

${ }^{52}$ Alonzo Smith and Quintard Taylor, "Racial Discrimination in the Workplace: A Study of Two West Coast Cities During the 1940s," The Journal of Ethnic Studies 8, no. 1 (1980): 36. 
required to pay regular dues, yet were not granted the rights and privileges conferred by full membership. Jim Crow auxiliaries were subordinated to the pre-existing union local, and their access to promotions, position changes, and even jobs relied on the goodwill and support of the white local union, with virtually no interference from the international union leadership. ${ }^{53}$

While national and international leadership in the CIO frequently stepped in to support Black workers, AFL leaders were much less likely to do so, making inclusion or exclusion of Black workers a hyperlocal issue. Although the international head of the AFL publicly spoke out against discriminatory practices in Portland and other AFL-affiliated locals, ${ }^{54}$ very little action was taken by the AFL. While the AFL publicly denounced discrimination when called upon to do so, it also continued to include unions which openly discriminated against Black people in their constitutions (such as the Boilermakers) or induction ceremonies. ${ }^{55}$ Even after chastisement from the AFL, the international vice-president of the Boilermakers openly defied FEPC directives to end discrimination in the union, responding to the directives with a letter wherein he denied FEPC jurisdiction, and claimed that President Franklin Roosevelt's Executive Order 9346, which strengthened the ban on discrimination in defense industries, lacked the force of law and was intended only as a guideline. ${ }^{56}$ Even the creation of Jim Crow auxiliaries seems to have been a ploy: because the CIO nominally accepted Black workers equally, the Boilermakers created a semblance of equality for competition's sake $;{ }^{57}$ in reality, the auxiliaries were crafted to maintain white privilege, by preventing Black workers from voting or achieving seniority and rights that would last after the war ended. ${ }^{58}$

\footnotetext{
${ }^{53}$ Edwin C. Berry, "Profiles: Portland," Journal of Educational Sociology 19, no. 3 (1945): 163.

54 “Negro Aides Win Approval," Oregonian, 28 October 1942, Newsbank/Readex.

${ }^{55}$ Kersten, Labor's Home Front, 77-79.

${ }^{56}$ Smith and Taylor, "Racial Discrimination in the Workplace," 41.

${ }^{57}$ Kersten, Labor's Home Front, 80.

${ }^{58}$ Smith and Taylor, "Racial Discrimination in the Workplace," 42-43.
} 
Other unions covering various aspects of work in the shipyards treated Black workers differently. While reporting on difficulties Black workers faced in Portland shipyards, the Oregonian spoke with the heads of several local unions in different trades, and reported that the Portland local of the International Hod Carriers' Building and Common Laborers of AmericaAFL was accepting Black workers as full members. Additionally, local unions for machinists, steamfitters, and painters were giving out work permits to any Black worker who applied for them, although most of these were for 'unskilled' helpers positions. ${ }^{59}$ In fact, skill designation was another significant factor in union acceptance and job hiring. Several 'unskilled' labor unions, as well as the International Brotherhood of Electrical Workers, accepted Black workers in some capacity, ${ }^{60}$ but these positions generally offered much less pay than skilled and semiskilled positions. Furthermore, they were a very small percentage of the jobs offered in Portlandarea shipyards: the Boilermakers represented $65 \%$ of shipyard workers across the nation, and "virtually all those employed in West Coast yards." ${ }^{161}$ As a result, breaking into the Boilermakers Local 72 was the only way that Black women would gain access to shipyard jobs in Portland, beyond poorly-paid janitorial work.

Both Black and white workers understood the importance of union opposition in preventing Black workers from gaining shipyard jobs. White migrant workers made note of the disparate treatment, and their reactions varied. Apparently assuming most of the Black workers were from the South, one white woman living in Vanport and working at the Swan Island shipyard speculated about their experience: "I am sure that there was not as much racial prejudice there, as there was in the states where the Negroes were from. However, there was

\footnotetext{
59 "Negro Shipyard Workers," Oregonian, 17 October 1942.

${ }^{60}$ Kesselman, Fleeting Opportunities, 40.

${ }^{61}$ Smith and Taylor, "Racial Discrimination in the Workplace," 36.
} 
prejudice." ${ }^{\circ 2}$ She witnessed the verbal harassment and threats faced by a "quiet, well dressed ... and very unassuming" Black man on the Portland-Vanport bus line without intervening, and wrote in her reflections: "Guess we are lucky to be born with white skin." ${ }^{\prime 3}$ She also noted that all of the Black women workers at the Swan Island shipyard were "on the cleaning crew who did the sweeping," ${ }^{64}$ because Kaiser had advertised seeking Black workers, but "the Boilermakers refused to let them join the Union." ${ }^{95}$

The obstinacy of the Boilermakers Local 72 was frequently reported upon by the Oregonian. Tommy Ray, secretary-treasurer and then president of Local 72, was repeatedly mentioned in the newspaper, often defending his positions against Black workers in the union. In March of 1942, the Portland Boilermakers Local 72 voted to remove the racial ban in their membership policy, "to permit the placing of qualified workmen, regardless of race," on the same night that the Portland school board adopted a resolution in which they condemned the Boilermakers for employment discrimination. ${ }^{66}$ In October 1942, the Oregonian reported on the results of a meeting between Ray, Anna Rosenberg (the New York regional director for the War Manpower Commission), Edgar Kaiser (vice-president and manager of Kaiser's Portland-area shipyards)s, and other Kaiser executives. ${ }^{67}$ According to the news report, "all American Federation of Labor unions which bar Negroes in the higher skill ratings agreed to admit Negroes to full membership or to waive closed shop rights to enable Negroes to work at the higher-paying skills without becoming union members." ${ }^{68}$ While leadership were meeting in New York, one New York City daily magazine sent a white journalist, Arnold Beichman, on the

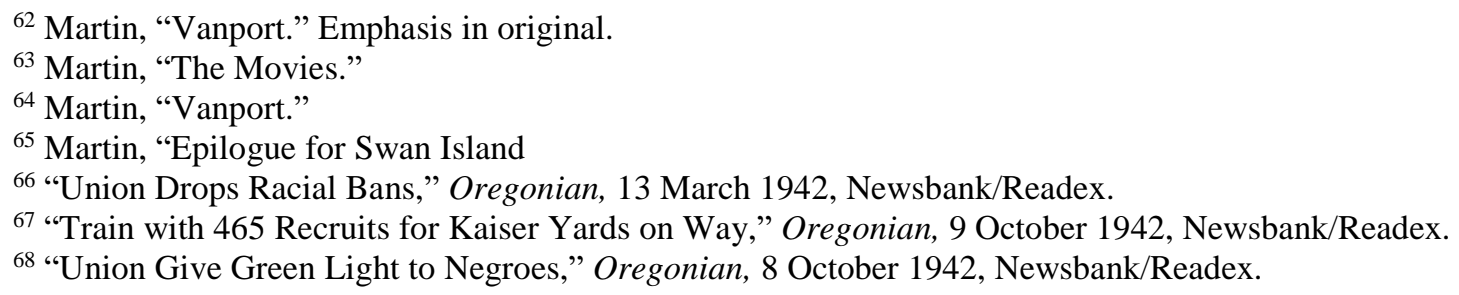


train to Oregon, with instructions to secure employment as a laborer in the shipyards. They subsequently published on the discrimination he witnessed. In his report, Beichman stated that Ray had told him plainly that he was "unalterably opposed to permitting Negroes to join the Boilermakers' Union," and that "if he was ordered to take Negroes into the union, he would quit." ${ }^{69}$ Within a week, Black workers at the Vancouver Kaiser shipyard threatened to strike, claiming that the meeting in New York had not produced any changes. ${ }^{70}$ In response, Kaiser officials agreed to reclassify several Black workers as journeymen, and extend job training to any who wanted it; as a result, the strike was canceled..$^{71}$ Almost immediately, the Portland Metal Trades Council and Ray objected, demanding that the workers be returned to their original classifications. Ray argued that Black workers from New York were being promoted over men who had been working there for months, which he deemed unfair. ${ }^{72}$ On the same day the Oregonian reported on Ray’s opposition, New York's PM published another report by Beichman, who wrote:

White workers from New York, originally hired as laborers, were upgraded without questioning, on the first Kaiser-bound train, from laborers at 88 cents an hour to helpers at 95 cents. I know because I was one of those upgraded in this wholesale fashion.

69 “Kaiser's Son Confers Here,” PM, 7 October 1942, retrieved from www.fultonhistory.com/fulton.html.

70 "Negro Shipyard Workers," Oregonian, 17 October 1942.

71 “Agreement Ends Walkout Threat," Oregonian, 19 October 1943, Newsbank/Readex.

72 “Union Leader Terms Negro Promotions Violation of Shipyards' Working Pact," Oregonian, 21 October 1942, Newsbank/Readex. 
He noted that Black workers were promoted individually, and that they were not likely to progress further up the ranks. ${ }^{73}$ Clearly, seniority was not as important as race in determining the upgrading of workers.

\section{Black Women at Work in Portland and Vancouver Shipyards}

The centrality of race was highlighted in another story run in the Oregonian that day, which reported that Ray "insisted that he would never permit women to serve as helpers to Negroes in the yards or to allow the colored men to work in the holds of ships with women." 74 There is no recognition of the existence of Black women in this statement: 'Negro' and 'woman' are treated as discrete categories, and it is almost certain that he is referring exclusively to white women. In the Portland shipyards, Black women often worked on crews composed almost entirely of Black women, and although some served as chippers or helpers, the vast majority worked in janitorial roles. ${ }^{75}$ In the Vancouver yard, more women were able to secure positions as welders and electricians, but were never able to achieve a representative share of Black skilled workers. ${ }^{76}$ Along with erasing Black women's presence in the yards, Ray intimated that Black workers might be supplanted by white women, a pool of labor that had not yet been fully utilized, ${ }^{77}$ and played on a common trope about Black people, casting Black men as rapists and seducers, dangerous to the morality and safety of white women. ${ }^{78}$ By calling up the specter of the

${ }^{73}$ Arnold Beichman, “AFL at Kaiser Still Lily White,” PM, 21 October 1942, retrieved from www.fultonhistory.com/fulton.html. In a piece published October 4, 1941, entitled “'Let Negroes Be Janitors,' Says Boilermakers Union," the Pittsburgh Courier reported that janitors made $\$ 0.77$ an hour, while boilermakers earned $\$ 1.25$ an hour.

74 “Negro-Yard Difficulty Near Crisis," Oregonian, 21 October 1942, Newsbank/Readex.

${ }^{75}$ Interview with Audrey Dotsey.

${ }^{76}$ Kesselman, Fleeting Opportunities, 41.

77 “Union Leader Terms Negro Promotions Violation," Oregonian, 21 October 1942.

${ }^{78}$ For more on this trope and its history, see: Angela Davis, Women, Race \& Class (1981), ch. 11; David Pilgrim, "The Brute Caricature," Ferris State University, last modified 2012, www.ferris.edu/jimcrow/brute/; Ida B. 
Black rapist, Ray cast himself in the heroic role of protector, justifying his continued opposition to Black workers in the shipyards. This created a seemingly natural division between white people and Black people, particularly between white women and Black men, incidentally denying the very existence of Black women.

Although the president of the AFL Metal Trades Department sent a telegram to the Portland Boilermakers and the Portland Metal Trades Council urging them to drop their demands for the demotion of the 23 Black workers reclassified to positions leading to journeyman's status, ${ }^{79}$ little was done to force the issue. Although another meeting between Kaiser and labor leaders was called for November 10th, this time in Portland, little seems to have come of it. The Oregonian noted that, while everything seemed to point to equal treatment for Black workers, what it looked like in reality would depend upon the actions taken by the union locals in charge of shipyard hiring and firing, under the closed shop agreement. ${ }^{80} \mathrm{~A}$ month later, it was optimistically reported that Black workers in applicable fields were to be granted access to union membership in the Boilermakers. ${ }^{81}$ Instead, the race debates of autumn 1942 led in December to the creation of an auxiliary for Black workers, Boilermakers Local A-32. ${ }^{82}$ Membership was compulsory: all Black workers in the yards were now required to join the auxiliary and pay dues, or face termination.

Wells-Barnett, Southern Horrors: Lynch Law in All its Phases (1894) and The Red Record: Tabulated Statistics and Alleged Causes of Lynching in the United States (1895). For an examination of this trope at work in World War II defense industries, see: Eileen Boris, “'You Wouldn't Want One of 'Em Dancing with Your Wife': Racialized Bodies on the Job in World War II," American Quarterly 50, no. 1 (1998): 77-108.

79 "Negro Aides Win Approval," Oregonian, 28 October 1942.

80 "Roosevelt Order Promises Work Equality to Negroes," Oregonian, 13 November 1942, Newsbank/Readex.

81 “Negroes Gain Union Rights," Oregonian, 12 December 1942, Newsbank/Readex.

82 "Negroes Oppose Auxiliary Union," Oregonian, 20 December 1942, Newsbank/Readex. 
The idea of an auxiliary exacerbated the already tense situation. As soon as the prospect was floated, workers in the Vancouver shipyard responded with a letter which read, in part, "We know what you've been trying to do about an auxiliary union for us, but we do not appreciate it at all. You may call it auxiliary, but we call it downright open discrimination and will not have

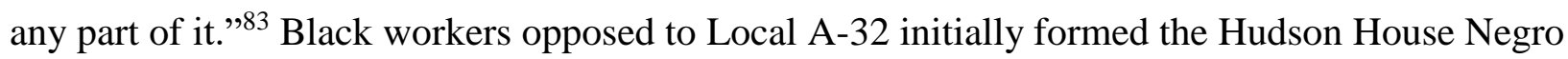
Victory Council in December 1942, a group comprised mainly of New Yorkers living in Vancouver and working in the Kaiser Vancouver yard ${ }^{84} \mathrm{~A}$ month later, the Portland chapter of the NAACP circulated a letter in support of the Hudson House Negro Victory Council, and asked other Black workers in the yards not to sign any petitions in support of an auxiliary, so as to avoid undermining the Vancouver group's struggle. ${ }^{85}$ In March 1943, the Hudson House group merged with Black workers from the Portland yards to form the Shipyard Negro Organization for Victory (SNOV) to address their shared experiences, not just with the Boilermakers, but with other aspects of life in the Portland-metropolitan area ${ }^{86}$ With the support of the NAACP, Black workers were finally given a hearing by the FEPC in November, albeit only after hundreds of Black workers were laid off for refusing to join the auxiliary union.

\section{Government Intervention: Successes and Failures}

By the time of the FEPC hearings, the president of Boilermakers Local 72 had been relieved of his position as a result of financial mismanagement, but this did little to help Black

83 “Negroes Oppose Auxiliary Union," Oregonian, 20 December 1942.

84 "Negroes in Victory Group to Combat Auxiliary Union," Oregonian, 20 December 1942, Newsbank/Readex.

85 “Negroes Laud Workers' Aim," Oregonian, 18 January 1943, Newsbank/Readex.

86 "Negros Form Own Council," Oregonian, 20 March 1943, Newsbank/Readex. Organization name reported by the Oregonian as the "Negro Shipyard Workers Victory council." 
workers. Legal counsel for Local 72 blamed the situation on the Boilermakers's international leadership, which had created the auxiliary system to begin with, and on the extreme prejudice of Oregon's white population. ${ }^{87}$ Edgar Kaiser cited his company's history of nondiscrimination policies, and argued that they would be quite happy to employ all eligible Black workers, except that their closed-shop agreement with the Boilermakers tied their hands. ${ }^{88}$ The international Boilermakers office refused to send representatives to the hearings, but the union's vicepresident spoke at the AFL convention that fall, and argued that segregation was a necessary compromise between unionists in the US South who desired racial exclusiveness, and more liberal-minded members living elsewhere who favored full integration. As far as the International leadership was concerned, the system was working fine everywhere except the Pacific Coast, where "professional Negro" leaders had stirred up division out of greed. ${ }^{89}$ Essentially, each party considered anyone but themselves the cause of the issue.

Through the hearings, where dozens of Black workers testified, the FEPC found strong evidence of discrimination, and ordered both the Kaiser company and the union to stop discrimination. Unfortunately for Black workers in the Portland and Vancouver yards, the FEPC lacked any real enforcement ability — the committee could not fine or otherwise sanction either entity. The Kaiser company requested a rehearing, arguing that the whole issue was with the union, and that labor relations laws forbade them from complying before the union did so. ${ }^{90}$ The FEPC held several more hearings over the next year, where the Kaiser company showed itself more reticent to fire Black workers than before. Meanwhile, the International Boilermakers

\footnotetext{
${ }^{87}$ Kersten, Labor's Home Front, 87-89.

${ }^{88}$ William H. Harris, "Federal Intervention in Union Discrimination: FEPC and West Coast Shipyards during World War II," Labor History 22, no. 3 (1981): 336.

${ }^{89}$ Kersten, Labor's Home Front, 89.

${ }^{90}$ Smith and Taylor, "Racial Discrimination in the Workplace," 41-42.
} 
restructured the auxiliary system, and then replaced it with a separate-but-equal segregated union system, neither of which complied with the FEPC directives. ${ }^{91}$ Kaiser and the Boilermakers stalled and protested, and the FEPC directives were never fully implemented in Oregon and Washington before the end of the war. The most successful case against the Boilermakers was a California court case, James et al v. Marinship Corporation, International Brotherhood of Iron Ship Builders and Helpers of America, et al, in which the California Supreme Court found that the International Boilermakers held a monopoly on shipyard employment, and was therefore a quasi-public body answerable to the needs of the community, and forbidden to discriminate in the way a social club might. ${ }^{92}$ This was an important long-term gain for California communities, but it came near the end of the war, and did not significantly impact the situation of workers in the Pacific Northwest.

The California Supreme Court decision reveals the large impact which local, state, and federal government could have on Black employment during the war. One area in which the government was particularly successful in supporting Black women workers during the war was in direct employment. As previously noted, US Navy shipyards accounted for a significant percentage of yards which hired Black women. Several Black women were hired to the Oregon office of the USES, assisting with job placement for migrant workers. ${ }^{93}$ Black women workers in Detroit found one of the few jobs readily available to them was work as government inspectors. ${ }^{94}$ The government also addressed the shortage of nurses during the war by expanding access to nursing education programs, and a significant number of Black women were able to become

\footnotetext{
${ }^{91}$ Kersten, Labor's Home Front, 91-92.

92 James v. Marinship Corp., 25 Cal. 2d 721 (1944).

${ }^{93}$ Interview with Kathryn Hall Bogle, 110-16.

94 Shockley, "Working for Democracy," 135.
} 
nurses as a result. ${ }^{95}$ Additionally, the wartime work of the FEPC prompted several states to create laws mandating equality in hiring and employment practices in the decade following the war. ${ }^{96}$ These laws helped set the stage for the civil rights battles which took place in the $1950 \mathrm{~s}$ and 1960s.

\section{Black Women Workers After the War}

Following the war, Black women continued to face significant difficulty finding work in the Portland area. Few manufacturers were wiling to hire Black women, and many women ended up in either garment manufacturing or domestic work. ${ }^{97}$ One woman waited tables in a restaurant, worked in a cannery, and dressed chickens. Working two jobs every day was so physically taxing that it caused her to miscarry at one point; after this, she went into private domestic work. ${ }^{98}$ Although Portland experienced an expansion in clerical and sales work for women, Black women were largely shut out of these occupations. ${ }^{99}$ In Vancouver, the USES had successfully placed Black workers in wholesale and retail positions during 1944, but by the end of 1945 were able to place fewer Black workers overall, and only in domestic service or in the rapidly shrinking shipbuilding industry. ${ }^{100}$ According to the 1950 census, $70.97 \%$ of working Black women in Oregon and $72.58 \%$ in Washington were still in private domestic work or

${ }^{95}$ Anderson, "Last Hired, First Fired," 90.

${ }^{96}$ B. R. Brazeal, "The Present Status and Programs of Fair Employment Practices Commissions-Federal, State, and Municipal," Journal of Negro Education 20, no. 3 (1951): 383-91. See also: Sidney Fine, “'A Jewel in the Crown of All of Us': Michigan Enacts aFair Employment Practices Act, 1941-1955," Michigan Historical Review 22, no. 1 (1996), 18-66.

${ }^{97}$ Kesselman, Fleeting Opportunities, 114-15.

${ }^{98}$ Interview with Audrey Dotsey.

${ }^{99}$ Kesselman, Fleeting Opportunities, 124-25.

${ }^{100}$ Robert O’Brien and Lee Brooks, "Race Relations in the Pacific Northwest," Phylon (1940-1956) 7, no. 1 (1946): 26-27. 
service sector work. ${ }^{101}$ While an improvement over the percentages of $1940-88.17 \%$ in Oregon and $84.14 \%$ in Washington ${ }^{102}$ - Black women's postwar options in Oregon and Washington were still heavily restricted to service work, whether in businesses or private homes.

By contrast, Black women in Detroit were able, through activist efforts, to secure department store and retail work by the mid-1950s. ${ }^{103}$ In addition, some factory workers were able to leverage their war experience and get reinstated after being laid off at the end of the war. Others were able to successfully petition local unions for support in getting factory work. ${ }^{104}$ Black women in the East Bay Area in California were successful in finding post-war work they could feel satisfied doing, with 1948 finding only $20 \%$ in private domestic service work, versus the $66 \%$ of Black women engaged in private service in 1940. In the East Bay, Black women could be found in manufacturing, clerical work and sales, and service-sector jobs, with the government accounting for much of the growth in clerical work, and very few Black women serving as retail workers. ${ }^{105}$ Although Black women across the country continued to resist restrictions in any way they could, the postwar economy was difficult to navigate, and many turned to service work, out of necessity. In Oregon and Washington, although the Black population of the 1950s was significantly larger than the prewar population, Black women workers remained largely confined to the most devalued work. Nevertheless, Black community members and their white allies may have been less willing to be complacent then they had been. The organizing spirit of the Second World War continued through the 1940s into the 1950s, setting the stage for the Civil Rights Movement of the 1950s and 1960s.

\footnotetext{
${ }^{101}$ Bureau of the Census, 1950 Census of the Population, Vol. 4, Pt. 3, Ch. 4, 3B 69-71.

${ }^{102}$ Bureau of the Census, Characteristics of the Nonwhite Population, 68.

103 Shockley, "Working for Democracy," 155.

${ }^{104}$ Shockley, "Working for Democracy," 150-53.

${ }^{105}$ Lemke-Santangelo, Abiding Courage, 107-08.
} 
Conclusion

Unlike the wartime experience of Black women in Chicago, Detroit, and similar cities, Black women in the Pacific Northwest found more resistance and restriction on their economic activity. While Black women workers in larger cities and boomtowns across the country were able to make some gains, those living in Portland and Vancouver met with much less success. This unique result may be attributed to the Boilermakers locals refusing Black workers membership, the historical repression which Black people faced in Oregon, and the reluctance or inability of various governmental bodies to force change. Furthermore, despite the increase in the Black population, the region remained overwhelmingly white. While the pre-war Black community conformed to a more accommodationist social model, the in-migrant community was less willing to wait for change, and this more forceful attitude carried forward into the post-war civil rights struggle. The World War II-era race issues in Oregon and Southwest Washington have been overshadowed by the legislative and cultural violence that came before and after the war, and by the racial dynamics in larger, more diverse cities. Nevertheless, increased study of this era will benefit our understanding of race in the mid-twentieth century Pacific Northwest.

Future research into this topic could investigate the work that Black women did outside of the shipyard in greater depth. Though many in-migrants to the area were recruited to work in shipyards, Black women workers were largely restricted to positions as common laborers and janitorial staff. Disappointment led many women to move to other boomtowns on the Pacific Coast, but others stayed in Portland and Vancouver, doing other kinds of work. Our understanding of the region's racial dynamics, and what lasting impact the war had on the community, could be increased by examining what motivated women to stay, and what kinds of 
work they found. Researchers would likely benefit from reaching out to the women still living today, and perhaps to their families, who traveled to Portland and Vancouver during the war to learn more details about their motivations. As a result of time constraints, it was not possible to travel to the California Bay Area to access the regional archives of the National Archives and Records Administration, nor to the archives in Washington, DC. Further research into relevant records there, particularly records of the FEPC's investigations in the Pacific Northwest, could answer some questions which were not addressed in this paper.

Scholars of Black women laborers during the Second World War have largely focused on those cities and towns which had significant Black communities before the war, or sustained such after the war. This leaves out smaller communities across the country which experienced quite different racial dynamics during and after the war. Studying the racial victories and setbacks of smaller cities like Portland and Vancouver helps scholars to better understand the racial tensions which carried forward and built up after the war. This paper is one entry in what will hopefully become a larger project, expanding our knowledge about Black populations of various sizes and geographic locations by examining the experiences of Black women workers on the US homefront. 


\section{Bibliography}

Anderson, Karen. "Last Hired, First Fired: Black Women Workers During World War II." Journal of American History 69, no. 1 (1982): 82-97.

Berry, Edwin C. “Profiles: Portland.” Journal of Educational Sociology 19, no. 3 (1945): 158-65.

Brazeal, B. R. "The Present Status and Programs of Fair Employment Practices CommissionsFederal, State, and Municipal.” Journal of Negro Education 20, no. 3 (1951): 378-97.

Bureau of the Census. 1940 Census of the Population: Characteristics of the Nonwhite Population by Race. Washington, DC: Government Printing Office, 1943.

Bureau of the Census. 1940 Census of the Population, Vol. 2: Characteristics of the Population. Pt. 7, Ch. 4. Washington, DC: Government Printing Office, 1943.

Bureau of the Census, 1950 Census of the Population, Vol. 4: Employment and Personal Characteristics, Pt. 3, Ch. 4. Washington, DC: Government Printing Office, 1943.

Harris, William H. "Federal Intervention in Union Discrimination: FEPC and West Coast Shipyards during World War II.” Labor History 22, no. 3 (1981): 325-47.

“History - Portland NAACP Branch 1120." Portland NAACP. Accessed 14 June 2017. http://www.portlandnaacp1120.org/history.html.

Hobbs, Frank, and Nicole Stoops. Demographic Trends in the 20th Century. Census 2000 Special Reports, Series CENSR-4. Washington, DC: Government Printing Office, November 2002.

Johannsen, Robert. "The Oregon Legislature of 1868 and the Fourteenth Amendment." Oregon Historical Quarterly 51, no. 1 (1950): 3-12.

Kersten, Andrew. Labor's Home Front: The American Federation of Labor During World War II. New York: NYU Press, 2009.

Kesselman, Amy. Fleeting Opportunities: Women Shipyard Workers in Portland and Vancouver During World War II and Reconversion. Albany: State University of New York Press, 1990. 
Kimble, Lionel, Jr. "I Too Serve America: African American Women War Workers in Chicago, 1940-1945.” Journal of the Illinois State Historical Society 93, no. 4 (2000/2001): 41534.

Lemke-Santangelo, Gretchen. Abiding Courage: African American Migrant Women and the East Bay Community. Chapel Hill: University of North Carolina Press, 1996.

Mangun, Kimberley. A Force for Change: Beatrice Morrow Cannady and the Struggle for Civil Rights in Oregon, 1912-1936. Corvallis: Oregon State University Press, 2010.

Martin, Irma. Manuscripts. Coll. 442.Oregon Historical Society Research Library, Portland.

McLagan, Elizabeth. A Peculiar Paradise: A History of Blacks in Oregon, 1788-1940. Portland: Georgian Press Company, 1980.

Newman, Dorothy K. Employing Women in Shipyards. Bulletin of the Women's Bureau, no. 192-6. Washington, DC: Government Printing Office, 1944.

O’Brien, Robert, and Lee Brooks. "Race Relations in the Pacific Northwest." Phylon (19401956) 7, no. 1 (1946): 21-31.

Oral history interview with Audrey Dotsey. By Amy Kesselman. 15 Jun. 1981. SR 9076. Transcript. Oregon Historical Society Research Library, Portland.

Oral history interview with Beatrice Green Marshall. By Madeline Moore and Christine Poole. 11 June 1981. SR 9081. Transcript. Oregon Historical Society Research Library, Portland.

Oral history interview with Kathryn and Richard Bogle, Sr. 20 October 1976. SR 0280. Sound recording. Oregon Historical Society Research Library, Portland.

Oral history interviews with Kathryn Hall Bogle. By Rick Harmon. 26 June 1985-28 Mar. 1986. SR 0422. Transcript. Oregon Historical Society Research Library, Portland.

Oregon Shipbuilding Corporation Photographic Collection. Org. Lot 686. Oregon Historical Society Research Library, Portland.

Pearson, Rudy N. "African Americans in Portland, Oregon, 1940-1950: Work and Living Conditions - A Social History." PhD diss., Washington State University, 1996. ProQuest (UMI 9711525). 
"Sign in Window of Unidentified Portland Business (Restaurant?) Reads, 'We Cater to White Trade Only." 1943. Jon Tuttle Collection, CN 023381. Oregon Historical Society Research Library, Portland.

Smith, Alonzo, and Quintard Taylor. "Racial Discrimination in the Workplace: A Study of Two West Coast Cities During the 1940s." The Journal of Ethnic Studies 8, no. 1 (1980): 3554.

Shockley, Megan T. "Working for Democracy: Working Class African-American Women, Citizenship, and Civil Rights in Detroit, 1940-1954." Michigan Historical Review 29, no. 2 (2003): 125-57.

Turk, Katherine. “'A Fair Chance to Do My Part of Work': Black Women, War Work, and Rights Claims at the Kingsbury Ordnance Plant.” Indiana Magazine of History 108, no. 3 (2012): 209-44. 